\title{
KNEE BIOMECHANICS AND PHYSICAL PERFORMANCE;
}

AN ACL-RECONSTRUCTED ATHLETE BEFORE AND AFTER ISOKINETIC STRENGTH TRAINING.

1. PhD Scholar

Physiotherapist,

Medical Section,

Pakistan Sports Board,

Kashmir Highway, Islamabad,

Pakistan.

2. $\mathrm{PhD}$

Associate Professor

Isra Institute of Rehabilitation

Sciences,

Isra University, Islamabad, Pakistan.

Correspondence Address:

Dr. Hafiz Muhammad Manan Haider

Khan

Physiotherapist,

Medical Section,

Pakistan Sports Board,

Kashmir Highway, Islamabad,

Pakistan.

mananbalouch@gmail.com

Article received on:

20/04/2017

Accepted for publication:

15/08/2017

Received after proof reading:

29/11/2017

\section{Hafiz Muhammad Manan Haider Khan', Tahir Masood ${ }^{2}$}

ABSTRACT... Introduction: A 29-year old male athlete (body mass: $64 \mathrm{~kg}$; height: $172 \mathrm{~cm}$ ) sustained complete ACL rupture of the right knee. He was a martial-arts player and the injury was repetitive, overuse in nature due to cyclic unilateral loading and unloading of the right knee during training sessions. Rupture was diagnosed through detailed patient history, clinical physical examination and was confirmed through magnetic resonance imaging (MRI) of the right knee. Surgical reconstruction of the ACL was planned and a patellar tendon graft was used. His baseline isokinetic data was recorded 4 months after the surgery. Objective: This case study describes the effects of isokinetic strength training on knee biomechanics and physical function of an ACL-reconstructed martial-arts athlete. Setting: Pakistan Sports Board Islamabad. Study period: 40 days. Materials and Methods: Biodex System 3 Pro was used to train the athlete for 15 sessions on alternate day basis. Average peak torque, average power, total work and peak torque to body weight ratio were recorded for hamstring and quadriceps before and after isokinetic rehabilitation. The athlete was positioned in the dynamometer with upright back while hip and knee were flexed to 90 degrees. Unilateral isokinetic contractions were performed according to a premeditated exercise protocol. Both hamstring and quadriceps were tested isokinetically at five different movement speeds (30deg/sec, $90 \mathrm{deg} / \mathrm{sec}, 150 \mathrm{deg} /$ $\mathrm{sec}, 210 \mathrm{deg} / \mathrm{sec}$, and $270 \mathrm{deg} / \mathrm{sec}$ ). Five contractions were performed at each speed during both knee flexion and extension. At baseline, average peak torque was higher at lower speeds for both hamstring and quadriceps. Results: As a result of rehabilitation, average peak torque for hamstring and quadriceps significantly improved at speeds of $150 \mathrm{deg} / \mathrm{sec}$ and $90 \mathrm{deg} / \mathrm{sec}$ respectively. Average power, peak torque to body weight ratio, total work was also improved for both hamstring and quadriceps. Two physical performance tests - agility run test and vertical jump test - were used to assess the effects of training and both performance tests improved $51 \%$ and $100 \%$ respectively. Conclusion: Isokinetic training improved the strength of quadriceps and hamstring after ACL reconstruction. Hamstring muscle demonstrated greater traininginduced increments in torque production compared to quadriceps at all contraction velocities.

Key words: $\quad A C L$ Reconstruction, isokinetic strength training, Biodex, Physical performance

Article Citation: Khan HMMH, Masood T. Knee biomechanics and physical performance; An acl-reconstructed athlete before and after isokinetic strength training. Professional Med J 2017;24(12):1921-1926. DOI:10.17957/TPMJ/17.3994

\section{INTRODUCTION}

The anterior cruciate ligament $(A C L)$ is one of the two diagonal ligaments that run within the knee joint. Main function of the ACL is to resist hyperextension of the knee joint and prevent anterior translation of the tibia on the femoral condyles thus stabilizing the knee joint. Despite its strength, ACL is prone to both acute and overuse injuries, especially in sports involving sharp turning, sudden stopping and starting. ${ }^{1}$ $\mathrm{ACL}$ injuries are associated with loss of knee musculature strength characterized by declined torque-production capacity of the hamstring and quadriceps. Other biomechanical symptoms of ACL rupture include loss of power, reduced capacity of muscle performance, knee laxity and pain. $^{2}$

Surgery is one of the options available for the management of ACL rupture. ACL reconstruction is a surgical procedure in which a graft from hamstring or patellar tendon is used to replace the torn ACL. Surgical success is reported for short term follow up in nearly $90 \%$ cases 
as reported by several studies. ${ }^{3,4,5}$ Physical rehabilitation after $A C L$ injuries and reconstruction traditionally involved prolonged immobilization, isometric exercises and non-weight bearing exercises. Modern approaches to post-surgical ACL rehabilitation favor early mobilization, early weight bearing exercises considered to develop more control at knee..$^{2,6}$

Strength training in a vital component of both the conservative management of the ACL ruptures as well the post-surgical physical rehabilitation. One of the regimes that have shown promising results in improving knee function in postsurgical $A C L$ patients is isokinetic training where the velocity of the movement is kept constant by the dynamometer. Isokinetic systems provide an efficient way to overload muscles for strength training. The limb attached with isokinetic dynamometer can be trained and tested at different pre set velocities. ${ }^{7}$ Isokinetic strength training has been reported to be an effective training tool in both healthy individuals ${ }^{8}$ and for injured. ${ }^{9,10}$

Regarding the symmetry of strength loss between knee muscle groups, it has been shown that knee extensors (the quadriceps) are affected more than the knee flexors (the hamstring) especially when patellar tendon graft is used for the reconstruction procedure. ${ }^{11}$ Restoration of muscle strength is crucial for an efficient and successful returnto-sport strategy. Hamstring strength training is advised because of its ability to posteriorly translate tibia so as to avoid stress on the graft. ${ }^{12}$ Since quadriceps muscle is more prone to lose strength, regaining of its strength has proved to be especially challenging. ${ }^{13,14,15}$

\section{CASE DISCUSSION}

A 29-year old male athlete (body mass: $64 \mathrm{~kg}$; height: $172 \mathrm{~cm}$ ) sustained complete ACL rupture of the right knee. He was a martial-arts player and the injury was repetitive, overuse in nature due to cyclic unilateral loading and unloading of the right knee during training sessions. Rupture was diagnosed through detailed patient history, clinical physical examination and was confirmed through magnetic resonance imaging (MRI) of the right knee. Surgical reconstruction of the ACL was planned and a patellar tendon graft was used. His baseline isokinetic data was recorded 4 months after the surgery.

\section{Assessment \& Treatment}

Isokinetic evaluation of the athlete was done 4 months after the reconstruction and subsequent physical rehabilitation regime devised. Prior to the isokinetic assessment, warm-up was achieved through running for 5 minutes on Biodex gait trainer and treadmill followed by sustained stretches of the hamstring and quadriceps muscles. Assessment was conducted on Biodex System 3 Pro (Biodex Medical Systems, Inc. NY, USA) using isokinetic mode. The athlete was positioned in the dynamometer with upright back while hip and knee were flexed to 90 degrees. Unilateral isokinetic contractions were performed according to a premeditated exercise protocol. Both hamstring and quadriceps were tested isokinetically at five different movement speeds (30deg/sec, 90deg/sec, 150deg/sec, 210deg/ $\mathrm{sec}$, and $270 \mathrm{deg} / \mathrm{sec}$ ). Five contractions were performed at each speed during both knee flexion and extension.

Assessment was done on following biomechanical and physical function parameters: average peak torque, peak torque-to-body weight ratio, average power, total mechanical work, agility run test time, and vertical jump height.

Average peak torque is average of maximum torque produced during the 5 repetitions at one speed and is indicative of muscular strength capability. Peak torque to body weight ratio is represented as percentage torque production normalized to body weight. Total work is the amount of mechanical work accomplished for the entire set i.e 5 contractions at required speed for both flexion and extension. This represents the muscle's capability to maintain torque throughout the test bout. Average power indicates the average rate of doing mechanical work during all contractions at a specific speed. ${ }^{16}$

Vertical jump test was used to determine the height of vertical jump. Illinois agility run test was 
used to measure the time taken to complete a 10 meter distance designed to check the agility of athlete.

After baseline evaluation, an isokinetic strength training regimen was devised for the athlete comprising 15 sessions of isokinetic knee flexion and extension at five training velocities carried out 3-4 times a week on Biodex System 3 Pro. Biomechanical Data was recorded during each session regarding biomechanical parameters while physical performance was evaluated after every 5 sessions.

\section{RESULTS}

At baseline, average peak torque was greatest at $30 \mathrm{deg} / \mathrm{sec}$ for both hamstring and quadriceps. Highest improvement for flexion (375\%) and extension (248\%) was seen at $150 \mathrm{deg} / \mathrm{sec}$ and $90 \mathrm{deg} / \mathrm{sec}$ respectively (Table-I).

\begin{tabular}{|l|c|c|c|}
\hline \multicolumn{4}{|c|}{ Average Peak Torque (ft.lbs) } \\
\hline & Plexion \\
\hline $30 \%$ sec & 20.4 & 49.6 & 143.1 \\
\hline $90 \%$ sec & 9 & 38.6 & 328.9 \\
\hline $150 \%$ sec & 8.4 & 39.9 & 375.0 \\
\hline $210 \%$ sec & 9 & 26.5 & 194.4 \\
\hline $270 \%$ sec & 9.4 & 28.4 & 202.1 \\
\hline & & Extension & \\
\hline & Pre & Post & $\Delta \%$ \\
\hline $30 \%$ sec & 28.5 & 53.3 & 87.0 \\
\hline $90 \%$ sec & 10.2 & 35.5 & 248.0 \\
\hline $150 \%$ sec & 8.8 & 29.4 & 234.1 \\
\hline $210 \%$ sec & 8.8 & 25.6 & 190.9 \\
\hline $270 \%$ sec & 8.8 & 22.1 & 151.1 \\
\hline \multicolumn{2}{|c|}{ Table-I. Average Peak Torque at all speeds for } \\
\hline \multicolumn{4}{|c|}{ hamstring and quadriceps } \\
\hline
\end{tabular}

Highest peak torque to body weight ratio was found at $30 \mathrm{deg} / \mathrm{sec}$ during initial assessment. Training-induced increment was greatest at 150 $\mathrm{deg} / \mathrm{sec}$ for hamstring (410\%) and at $270 \mathrm{deg} / \mathrm{sec}$ for quadriceps (218\%) (Table-II).

At baseline, hamstring produced highest total work at $270 \mathrm{deg} / \mathrm{sec}$ and quadriceps at $30 \mathrm{deg} /$ sec. Total work during flexion showed over 8-fold rise at $30 \mathrm{deg} / \mathrm{sec}$ and nearly 5.5 times during extension at $90 \mathrm{deg} / \mathrm{sec}$ (Table-III).

\begin{tabular}{|c|c|c|c|}
\hline \multicolumn{3}{|c|}{ Peak Torque / Body Weight } \\
\hline & Plexion \\
\hline & 15.8 & 36.6 & 131.6 \\
\hline $30 \%$ sec & 6.8 & 31.4 & 361.8 \\
\hline $90 \%$ sec & 6.9 & 35.2 & 410.1 \\
\hline $150 \%$ sec & 6.8 & 22.5 & 230.9 \\
\hline $210 \%$ sec & 8.2 & 22.5 & 174.4 \\
\hline $270 \%$ sec & & Extension & \\
\hline & Pre & Post & $\Delta \%$ \\
\hline $30 \%$ sec & 23.5 & 42.4 & 80.4 \\
\hline $90 \%$ sec & 11.5 & 29.3 & 154.8 \\
\hline $150 \%$ sec & 7.6 & 23.9 & 214.5 \\
\hline $210 \%$ sec & 7.9 & 19.8 & 150.6 \\
\hline $270 \%$ sec & 6.9 & 22 & 218.8 \\
\hline Table-II. Peak Torque to body weight ratio at all \\
\hline speeds for hamstring and quadriceps
\end{tabular}

\begin{tabular}{|c|c|c|c|}
\hline \multicolumn{4}{|c|}{ Total Work (ft.lbs) } \\
\hline & \multicolumn{3}{|c|}{ Flexion } \\
\hline & Pre & Post & $\Delta \%$ \\
\hline $30 \%$ sec & 33.7 & 271 & 704.2 \\
\hline $90 \%$ sec & 30.4 & 240.6 & 691.4 \\
\hline $150 \%$ sec & 31.7 & 231.6 & 630.6 \\
\hline $210 \%$ sec & 30.7 & 143.6 & 367.8 \\
\hline $270 \%$ sec & 37.6 & 83.5 & 122.1 \\
\hline & & Extension & \\
\hline & & Post & $\Delta \%$ \\
\hline $30 \%$ sec & 94.7 & 266.6 & 181.5 \\
\hline $90 \%$ sec & 36.3 & 197.9 & 445.2 \\
\hline $150 \%$ sec & 34.8 & 154.7 & 344.5 \\
\hline $210 \%$ sec & 28.5 & 95.4 & 234.7 \\
\hline $270 \%$ sec & 29.8 & 54.8 & 83.9 \\
\hline Table-III. Total Work at all speeds for hamstring and \\
\hline
\end{tabular}

Before training, average power during flexion was greatest at $270 \mathrm{deg} / \mathrm{sec}$ and at $150 \mathrm{deg} /$ sec for extension. Most marked training-induced improvement for both flexion (527\%) and extension (314\%) was observed at $90 \mathrm{deg} / \mathrm{sec}$ (Table-IV).

At baseline, agility run test time was 29.1 seconds and vertical jump was $11 \mathrm{~cm}$ which improved after 15 sessions $51 \%$ and $100 \%$ respectively (Table-V). 


\begin{tabular}{|c|c|c|c|}
\hline \multicolumn{4}{|c|}{ Average Power (Watts) } \\
\hline & \multicolumn{3}{|c|}{ Flexion } \\
\hline & Pre & Post & $\Delta \%$ \\
\hline $30 \% / \mathrm{sec}$ & 9.6 & 24.9 & 159.4 \\
\hline $90 \% / \mathrm{sec}$ & 7.6 & 47.7 & 527.6 \\
\hline $150^{\circ} / \mathrm{sec}$ & 9.8 & 61 & 522.4 \\
\hline $210^{\circ} / \mathrm{sec}$ & 10.8 & 40.8 & 277.8 \\
\hline \multirow[t]{3}{*}{$270 \% / \mathrm{sec}$} & 13.6 & 28.2 & 107.4 \\
\hline & \multicolumn{3}{|c|}{ Extension } \\
\hline & Pre & Post & $\Delta \%$ \\
\hline $30 \% / \mathrm{sec}$ & 10.9 & 24 & 120.2 \\
\hline $90 \% / \mathrm{sec}$ & 9.5 & 39.4 & 314.7 \\
\hline $150^{\circ} / \mathrm{sec}$ & 11.8 & 41.4 & 250.8 \\
\hline $210^{\circ} / \mathrm{sec}$ & 11 & 25.4 & 130.9 \\
\hline $270^{\circ} / \mathrm{sec}$ & 11.7 & 15.4 & 31.6 \\
\hline \multicolumn{4}{|c|}{$\begin{array}{l}\text { Table-IV. Average Power all speeds for hamstring anc } \\
\text { quadriceps }\end{array}$} \\
\hline
\end{tabular}

\begin{tabular}{|c|c|c|}
\hline \multicolumn{3}{|c|}{ Physical Performance } \\
\hline \multicolumn{3}{|c|}{ Agility Run Test time (sec) } \\
\hline Pre & Post & $\Delta \%$ \\
\hline 29.1 & 19.2 & 51.7 \\
\hline & Vertical Jump Height (cm) \\
\hline Pre & Post & $\Delta \%$ \\
\hline 11 & 22 & 100.0 \\
\hline \multicolumn{2}{|c|}{ Table-V. Physical performance test } \\
\hline
\end{tabular}

\section{DISCUSSION}

Average peak torque is a determinant of force of muscular strength during all repetitions at a given speed for hamstring and quadriceps. Average peak torque is usually reduced as the muscle shortening velocity increases due to an inverse force-velocity relation during concentric contractions. ${ }^{17}$ It has been reported that at higher movement speed, less torque is produced and lesser motor units are activated..$^{18}$ Our study findings were similar to the findings of earlier studies that highest average peak torque produced at baseline for hamstring was $20.4 \mathrm{ft}-\mathrm{lbs}$ and $9.4 \mathrm{ft}-\mathrm{lbs}$ at speed of $30 \mathrm{deg} / \mathrm{sec}$ and $270 \mathrm{deg} / \mathrm{sec}$ respectively. For quadriceps it was $28.5 \mathrm{ft}-\mathrm{lbs}$ and $8.8 \mathrm{ft}-\mathrm{lbs}$ at speed of $30 \mathrm{deg} /$ sec and $270 \mathrm{deg} / \mathrm{sec}$ respectively at baseline. Average peak torque after training improved at all speed but significant improvement for hamstring was at speed of $150 \mathrm{deg} / \mathrm{sec}$ and for quadriceps at speed of $90 \mathrm{deg} / \mathrm{sec}$. Least improvement for hamstring was $143 \%$ and for quadriceps $87 \%$ at speed of $30 \mathrm{deg} / \mathrm{sec}$. A past study has reported that significant improvement at higher speed $180 \mathrm{deg} / \mathrm{sec}$ for hamstring and a slower speed 60 $\mathrm{deg} / \mathrm{sec}$ for quadriceps. ${ }^{19}$ Increments in average peak torque at all velocities during both flexion and extension indicate an overall improvement in muscle strength thus confirming the findings of several other studies. ${ }^{20,21,22}$

Peak torque to body weight ratio which shows production of peak torque normalized to body weight was lower at higher speeds at baseline for both hamstrings and quadriceps. One study showed that with training peak torque to body weight ratio is higher at highest speed 180deg/ $\mathrm{sec}$ as compared to $60 \mathrm{deg} / \mathrm{sec}$ for both flexors and extensors. ${ }^{23}$ At baseline peak torque to body ratio was greater at $30 \mathrm{deg} / \mathrm{sec}$ speed for both hamstring and quadriceps. Our study showed training at higher speed $150 \mathrm{deg} / \mathrm{sec}$ for hamstring and $270 \mathrm{deg} / \mathrm{sec}$ for quadriceps improved peak torque to body weight ratio significantly. As peak torque significantly improved and body weight remained the same it showed marked increase in ratio. Peak torque to body weight ratio was least improved for both hamstring and quadriceps was at speed of $30 \mathrm{deg} / \mathrm{sec}$ which was $131 \%$ and $80 \%$ respectively.

Total work is product of force and displacement. One earlier study conducted showed that total work for quadriceps was greater at low speeds i.e $60 \mathrm{deg} / \mathrm{sec} .^{24}$ Our study showed that greater work for quadriceps was at the speed of 30 $\mathrm{deg} / \mathrm{sec}$ at baseline and for hamstring it was greater at $270 \mathrm{deg} / \mathrm{sec}$ at baseline. Greater improvement was there for hamstring at speed $90 \mathrm{deg} / \mathrm{sec}$ for hamstrings and $30 \mathrm{deg} / \mathrm{sec}$ for quadriceps in our study. Since work is product of force and displacement and in our study both these components improved, therefore work improved too. This finding is also supported by earlier conducted study. ${ }^{25}$ in our study the less improvement in total work was at speed of 270 $\mathrm{deg} / \mathrm{sec}$ for both hamstring and quadriceps.

Average power shows how quickly a muscle can produce force. Power is lower at higher velocities one earlier study reported. ${ }^{26}$ Our subject's findings contradict these findings since higher 
average power was recorded at higher velocity at baseline in our study. The hamstring power was greater at speed of $270 \mathrm{deg} / \mathrm{sec}$ and quadriceps at $150 \mathrm{deg} / \mathrm{sec}$. Our study confirms the finding of an earlier study which reported average power was greater for both hamstring and quadriceps at higher velocity of $180 \mathrm{deg} / \mathrm{sec}$ as compared to $60 \mathrm{deg} / \mathrm{sec}^{19} \mathrm{~A}$ remarkable increase (hamstring $527 \%$ and $314 \%$ quadriceps) was there at speed of $90 \mathrm{deg} / \mathrm{sec}$. Not much of improvement was recorded for both hamstring and quadriceps at speed of $270 \mathrm{deg} / \mathrm{sec}$.

Physical performance test was used to see the improvement in physical performance. Regarding physical performance, agility run test time improved substantially (51\%) from 29.2 seconds, at baseline, to 19.2 seconds after training. Postrehabilitation performance would still be ranked below average based on the normative data available. ${ }^{26,27}$ One already conducted study showed significant correlation between average peak torque at higher velocities and vertical jump..$^{28}$ Our findings are in agreement to earlier reports regarding improved physical performance after isokinetic strength training. ${ }^{29}$

\section{CONCLUSION}

This novel study has demonstrated that isokinetic strength training markedly improved physical function and knee joint kinetics in the anterior cruciate ligament reconstructed patient. Hamstring muscle demonstrated greater training-induced increments in torque production compared to quadriceps at all contraction velocities. Further studies with larger sample size and control group are recommended to confirm the findings of this case study in Pakistan.

Copyright@ 15 Aug, 2017.

\section{REFERENCES}

1. Marx RG, Myklebust G. The ACL Solution: Prevention and Recovery for Sports' Most Devastating Knee Injury. Demos Medical Publishing; 2012 Jun 19.

2. Risberg MA, Holm I, Tjomsland O, Ljunggren E, Ekeland A. Prospective study of changes in impairments and disabilities after anterior cruciate ligament reconstruction. Journal of Orthopaedic \& Sports Physical Therapy. 1999 Jul; 29(7):400-12.
3. Ardern CL, Webster KE, Taylor NF, Feller JA. Return to sport following anterior cruciate ligament reconstruction surgery: a systematic review and meta-analysis of the state of play. British journal of sports medicine. 2011 Mar 11:bjsports76364.

4. Thomeé R, Kaplan Y, Kvist J, Myklebust G, Risberg MA, Theisen D, Tsepis E, Werner S, Wondrasch B, Witvrouw $E$. Muscle strength and hop performance criteria prior to return to sports after ACL reconstruction. Knee Surgery, Sports Traumatology, Arthroscopy. 2011 Nov 1; 19(11):1798-805.

5. De Valk EJ, Moen MH, Winters M, Bakker EW, Tamminga $\mathrm{R}$, van der Hoeven $\mathrm{H}$. Preoperative patient and injury factors of successful rehabilitation after anterior cruciate ligament reconstruction with single-bundle techniques. Arthroscopy: The Journal of Arthroscopic \& Related Surgery. 2013 Nov 30; 29(11):1879-95.

6. Shelbourne KD, Klootwyk TE, Wilckens JH, Mark S. Ligament stability two to six years after anterior cruciate ligament reconstruction with autogenous patellar tendon graft and participation in accelerated rehabilitation program. The American journal of sports medicine. 1995 Sep 1; 23(5):575-9.

7. Guedes R, Bottaro M, Magalhães I, Trindade $M$, Brown LE, Carmo JD, Carregaro RL. The effects of Kinesiotaping on quadriceps muscle performance at different velocities: $A$ randomized controlled trial. Isokinetics and Exercise Science. 2016(Preprint):1-8.

8. Nickols-Richardson, S.M., Miller, L.E., Wootten, D.F., Ramp, W.K. and Herbert, W.G., 2007. Concentric and eccentric isokinetic resistance training similarly increases muscular strength, fat-free soft tissue mass, and specific bone mineral measurements in young women. Osteoporosis international, 18(6), pp.789-796.

9. Nickols-Richardson SM, Miller LE, Wootten DF, Ramp WK, Herbert WG. Concentric and eccentric isokinetic resistance training similarly increases muscular strength, fat-free soft tissue mass, and specific bone mineral measurements in young women. Osteoporosis international. 2007 Jun 1; 18(6):789-96.

10. Aquino MD, Leme LE. Isokinetic dynamometry in elderly women undergoing total knee arthroplasty: a comparative study. Clinics. 2006 Jun; 61 (3):215-22.

11. Keays SL, Bullock-Saxton J, Keays AC. Strength and function before and after anterior cruciate ligament reconstruction. Clinical orthopaedics and related research. $2000 \mathrm{Apr} 1$; 373:174-83.

12. Hurley MV, Jones DW, Wilson D, Newham DJ. Rehabilitation of quadriceps inhibited due to isolated 
rupture of the anterior cruciate ligament. Journal of Orthopaedic Rheumatology. 1992 Sep 1; 5(3):145-54.

13. Urbach D, Nebelung W, Becker R, Awiszus F. Effects of reconstruction of the anterior cruciate ligament on voluntary activation of quadriceps femoris. Bone \& Joint Journal. 2001 Nov 1; 83(8):1104-10.

14. Eriksson E. Rehabilitation of muscle function after sport injury-major problem in sports medicine. International journal of sports medicine. 1981 Feb; 2(01):1-6.

15. Kawakami Y, Kubo K, Kanehisa H, Fukunaga T. Effect of series elasticity on isokinetic torque-angle relationship in humans. European Journal of Applied Physiology. 2002 Jan 1; 87(4-5):381-7.

16. www.biodex.com/sites/default/files/data.pdf

17. Huang $M H$, Lin $Y S$, Yang RC, Lee CL. A comparison of various therapeutic exercises on the functional status of patients with knee osteoarthritis. In Seminars in arthritis and rheumatism 2003 Jun 30 (Vol. 32, No. 6, pp. 398-406). WB Saunders.

18. Cvjetkovic DD, Bijeljac S, Palija S, Talic G, Radulovic TN, Kosanovic MG, Manojlovic S. Isokinetic testing in evaluation rehabilitation outcome after ACL reconstruction. Medical Archives. 2015 Feb; 69(1):21.

19. Pincivero DM, Lephart SM, Karunakara RG. Effects of rest interval on isokinetic strength and functional performance after short-term high intensity training. British journal of sports medicine. 1997 Sep 1; 31(3):22934.

20. Rutherford OM, Greig CA, Sargeant AJ, Jones DA. Strength training and power output: transference effects in the human quadriceps muscle. Journal of sports sciences. 1986 Sep 1; 4(2):101-7.

21. Thorstensson A, Hultén B, Döbeln WV, Karlsson J.
Effect of strength training on enzyme activities and fibre characteristics in human skeletal muscle. Acta Physiologica Scandinavica. 1976 Mar 1; 96(3):392-8.

22. Moritani T, Devries HA. Potential for gross muscle hypertrophy in older men. Journal of Gerontology. 1980 Sep 1; 35(5):672-82.

23. Ozkaya N, Nordin M. Viscoelasticity and biological tissues. Fundamentals of biomechanicsequilibrium, motion and deformation. New York: Van Nostrand Reinhold. 1991:333-53.

24. Whipple $\mathrm{RH}$, Wolfson $\mathrm{LI}$, Amerman PM. The relationship of knee and ankle weakness to falls in nursing home residents: an isokinetic study. Journal of the American Geriatrics Society. 1987 Jan 1; 35(1):13-20.

25. Mannion AF, Jakeman PM, Willan PL. Effects of isokinetic training of the knee extensors on highintensity exercise performance and skeletal muscle buffering. European journal of applied physiology and occupational physiology. 1994 Jul 1; 68(4):356-61.

26. Roozen M. Illinois agility test. NSCA's Performance Training Journal. 2004; 3(5):5-6.

27. www.topendsports.com/testing/norms/vertical-jump. htm.

28. Wilk KE, Romaniello WT, Soscia SM, Arrigo CA, Andrews $J R$. The relationship between subjective knee scores, isokinetic testing, and functional testing in the ACLreconstructed knee 1. Journal of Orthopaedic \& Sports Physical Therapy. 1994 Aug; 20(2):60-73.

29. Anderson MA, Gieck JH, Perrin D, Weltman A, Rutt $\mathrm{R}$, Denegar $\mathrm{C}$. The relationships among isometric, isotonic, and isokinetic concentric and eccentric quadriceps and hamstring force and three components of athletic performance. Journal of Orthopaedic \& Sports Physical Therapy. 1991 Sep; 14(3):114-20.

\section{AUTHORSHIP AND CONTRIBUTION DECLARATION}

\begin{tabular}{|c|l|l|}
\hline Sr. \# & \multicolumn{1}{|c|}{ Author-s Full Name } & \multicolumn{1}{c|}{ Contribution to the paper } \\
\hline 1 & $\begin{array}{l}\text { Hafiz M. Manan Haider } \\
\text { Khan }\end{array}$ & $\begin{array}{l}\text { Conception and design of the } \\
\text { work, Data collection, Analysis and } \\
\text { interpretation of data. Revising it } \\
\text { critically and final approval of the } \\
\text { article to be published, Accountable } \\
\text { for all aspects of the work. } \\
\text { Conception and design of the } \\
\text { work, Analysis and interpretation of } \\
\text { data. Revising it critically and final } \\
\text { approval of the article be published, } \\
\text { accountalbe for all aspects of the } \\
\text { work. }\end{array}$ \\
\hline
\end{tabular}

